\title{
BAILEE'S LIABILITY FOR FAILURE TO WARN BAILOR OF LACK OF INSURANCE: SOURCE OF THE DUTY OF CARE \\ M. M. LITMAN*
}

The writer presents a detailed analysis of a recent torts case. The case is used as a vehicle for examination of several broader legal issues such as: the scope of the duty of affirmative care generated by the relationship of bailment, the characteristics of relationships which give rise to duties of affirmative care, misfeasance versus nonfeasance, and the principle of Hedley Byrne.

\section{INTRODUCTION}

In the recent decision of the Supreme Court of British Columbia in Mason et al. v. Morrow's Moving and Storage Ltd. et al. ${ }^{1}$ the defendant corporation, a bailee warehouseman, was found liable for being in breach of its duty to inform the plaintiff bailors that their goods were uninsured. The decision is problematic because in his reasons for judgment $\mathrm{Mr}$. Justice McKenzie did not clearly delineate the source of the rather unusual duty of care upon which the corporation's negligence was founded. It is the source of this unusual duty of care with which this comment is primarily concerned. As well, this comment will draw attention to what this writer believes to be a potentially serious theoretical problem with McKenzie J.'s judgment. The discussion of these matters will necessitate an examination of the following points:

1. The scope of the duty of affirmative care generated by the relationship of bailment;

2. The question of whether the corporate defendant's liability was based on misfeasance or nonfeasance;

3. The characteristics of those special relations which give rise to duties of affirmative care;

4. The nature of the plaintiffs' damages-purely economic loss-and its implications for the decision;

5. The question of what is a misrepresentation; and

6. The question of whether the principle of Hedley Byrne \& Co. v. Heller \& Partners $L t d .{ }^{2}$ is capable of rationalizing McKenzie J.'s decision.

\section{THE FACTS}

The plaintiff Fraser's and the plaintiffs Masons' household goods were destroyed by a fire which also destroyed the corporate defendant's warehouse in which the goods were stored.

Prior to the plaintiffs shipping their goods to the warehouse, Banman, who was the controlling shareholder of the corporate defendant and who was active in the company's business affairs, suggested to the plaintiffs that they let him "arrange everything from his end."3 The plaintiffs, however, by hiring movers themselves, did not accede to this suggestion. Ordinarily, upon arrival of its customers' goods at its warehouse the

- LL.B. (Osgoode), Assistant Professor of Law, University of Alberta.

1. (1977) 2 C.C.L.T. 118 (B.C.S.C.), [1977] 2 W.W.R. 738: See also annotation (1977) 2 C.C.L.T. 119.

2 [1963] 2 All E.R. 575 (H.L.), [1964] A.C. 465.

3. Supra, n. 1 C.C.L.T. at 132, W.W.R. at 749. 
defendant corporation informed its customers that their goods were uninsured and that if they wanted insurance they would have to place it themselves. When the plaintiffs' goods arrived, contrary to the defendant's usual procedure, the insurance situation was not elucidated to them. Some months later the plaintiff Mason's television set was damaged while in storage. During ensuing discussions between the plaintiffs Mason and Banman, who, as McKenzie J. took pains to point out, had grown to be friends, ${ }^{4}$ the Masons were told that there was insurance to cover this loss. The only insurance which the corporate defendant had was liability insurance. Subsequently, the plaintiffs' goods were burned when an employee of the corporate defendant set fire to the warehouse. The employee was charged with arson but was found not guilty by reason of insanity. The plaintiffs sued the corporate defendant alleging, inter alia, negligence in failing to provide safe storage and alternatively, in failing to warn the plaintiffs that insurance coverage was not being provided.

\section{THE DECISION}

McKenzie J. found that the defendant corporation was not responsible for the act of its employee. Neither could the employee's act have been reasonably foreseen, nor did it fall within the scope of his employment: 5

I find that ... [the employee's] conduct was entirely unpredictable and aberrational and certainly it was not within the scope or course of his employment. Temporarily he was not even employed.

Furthermore, McKenzie J. had no difficulty in concluding that the corporate defendant had provided safe storage. It had exercised reasonable care in providing an appropriate storage facility: 6

... I hold that the corporate defendant provided an adequate storage place by contemporary standards and that he was not obliged to add such refinements as . . . [a fire alarm system or a sentry system or sprinkler system]. He is not obliged to make his premises absolutely safe.

The difficult point in the case was whether or not the corporate defendant bailee was under an obligation to inform the plaintiff bailors of the lack of insurance coverage. How did McKenzie J. approach this issue? After noting that counsel, despite diligent search, had found no law on the question he stated: ${ }^{7}$

The only recourse is to first principles, to look at the facts in their light to see whether or not the corporate defendant met the objective standard of care required of him.

This is an unfortunate way of characterizing the issue because it presupposes the very point in issue; that is, the existence of a duty to warn the plaintiffs of the insurance situation. Once the existence of such a duty of care is established it seems quite clear in the circumstances of the case, that the corporate defendant did not satisfy the objective standard of care required of it.

At no point in his reasons for judgment did McKenzie J. directly pose the question of whether the corporate defendant was duty bound to

\footnotetext{
4. Supra, n. 1. C.C.L.T. at 125 and 132, W.W.R. at 742 and 749. It should be noted that Mrs. Fraser was party to the friendship. The importance of this fact will shortly become apparent.

5. Supra, n. 1. C.C.L.T. at 131, W.W.R. at 747.

6. Id. C.C.L.T. at 131, W.W.R. at 748.

7. Id. C.C.L.T. at 132 ,W.W.R. at 748.
} 
inform the plaintiffs of their lack of insurance. However, he did conclude that the corporate defendant was under such a duty of care: ${ }^{8}$

The warehouseman's duty of care carried forward to the point of informing and no further but here the warehouseman failed to take that routine step.

Once again this assumes rather than proves the proposition in question.

It would be unfair to suggest, however, that McKenzie J. did not provide any guidance as to the source of the corporate defendant's duty of care. His judgment emphasized two points which, individually or taken together, could well have been the source of the corporate defendant's obligation. In the first place he stressed the special and unique relationship of the parties. He noted that the parties were not simply involved in an arms-length business relationship, but had developed a social relationship. He concluded by saying: ${ }^{9}$

... [The plaintiffs] relied on Banman not only as a newly acquired friend but as an expert in his field. ... The[ir] relationship was something more than an impersonal business relationship. . . . [emphasis mine]

The implication that flows from characterizing the parties' relationship in this manner is that the plaintiffs had more reason to rely on the corporate defendant for protection of their interests than would other customers of the corporate defendant. The second source of the corporate defendant's duty of care was found in its misconduct. McKenzie J. suggested that the corporate defendant "lulled" the plaintiffs into the false belief that "the whole matter of protection, including fire insurance protection" was in its hands. 10

How were the plaintiffs lulled into their mistaken belief? Unfortunately McKenzie J.'s reasons for judgment do not provide a specific answer to this question. However, it is difficult to escape the conclusion that in McKenzie J.'s view the plaintiffs' mistaken belief was, at least in part, attributable to certain statements or representations made to them by Banman. McKenzie J.'s reasons for judgment reveal two representations that could possibly have been construed by them as indicating that the corporate defendant had assumed a protective role in respect of their interests, which included the placing of insurance against the risk of fire. In the first place, Banman suggested to the plaintiffs that he arrange "everything from his end."11 Presumably, "everything" could well include the placing of fire insurance. Secondly, Banman told the plaintiffs Mason that their television set, which had been damaged in storage, was covered by insurance. The incident leading to this second representation and the effect of the representation on the plaintiffs' state of mind was carefully summarized by McKenzie J. After finding as a fact that the plaintiffs were unaware of fire insurance coverage, McKenzie J. continued: ${ }^{12}$

They took it for granted that the warehouseman was fully responsible for safe storage and safe return. This assumption was given support by the fact that sometime in 1971 a television set held in storage for the Masons was damaged and in the discussion between Banman and Mason, Banman disclosed that there was insurance to cover the loss and that the loss would be made good when the effects were taken out of storage. I find that Banman was talking about liability insurance and that he was suggesting that his liability policy would have to respond to a negligence claim. He was talking

\footnotetext{
8. Id. C.C.L.T. at 133, W.W.R. at 750 .

9. Id. C.C.L.T. at 132 , W.W.R. at 749 .

10. Id. C.C.L.T. at 133, W.W.R. at 749-750.

11. Supra, n. 3.

12. Supra, n. 1. C.C.L.T. at 127 and 128, W.W.R. at 744.
} 
about the result when 'there was carelessness on our part'. I find also, however, that Mason did not distinguish in his mind between liability coverage and risk coverage. $\mathrm{He}$ got the simple message that there was insurance and once again had nothing to prompt him to suspect that he alone was responsible to purchase risk insurance.

It should be noted for purposes of later discussion that though this representation was made to the plaintiffs Mason, McKenzie J. seemed to consider the plaintiff Fraser's belief as also having been affected by the representation. Whether or not McKenzie J. was correct in concluding that the special relationship of the parties or the representations made to them or the combination of these two factors justified the imposition upon the corporate defendant of a duty to inform the plaintiffs of the lack of insurance coverage will also be discussed later in this comment.

\section{THE CONCEPTUAL BASIS OF THE CORPORATE DEFENDANT'S LIABILITY}

While it cannot be doubted that the general basis of the corporate defendant's liability was negligence, the precise category of negligence into which the case fits is obscure. Was the corporate defendant's liability based on misfeasance or nonfeasance? If nonfeasance, what was the source of the special duty of care which converted the defendant corporation's failure to take affirmative steps into an actionable wrong? If misfeasance, does the nature of the plaintiffs' damages-economic loss-preclude the plaintiffs from recovering on the basis of a conventional negligence action? The case leaves it to its readers to resolve these difficult and important problems.

\section{MISFEASANCE $v$. NONFEASANCE: THE NONFEASANCE THEORY OF THE CASE}

At first sight the case appears to be one of nonfeasance. Liability is being imposed upon the corporate defendant for its failure to take the affirmative action of warning the plaintiffs that it was not providing insurance coverage. Assuming, for the moment, that this indeed is a case of nonfeasance, one must inquire into the source of the special duty of care which would render this nonfeasance actionable. Numerous writers have pointed out that the general duty of care one owes to one's "neighbour" is insufficient to support an action based on nonfeasance. ${ }^{13}$

The law recognizes that certain special relations give rise to duties of affirmative care. Employer-employee, occupier-lawful visitor, driverpassenger and bailor-bailee are examples of these special relations. In these relations the employer, the occupier, the driver and the bailee have all been burdened with the obligation of taking positive steps to benefit their partners. Because the parties in the instant case were involved in a relationship of bailment it is important to determine the scope of the duty of affirmative care generated by that relationship. Was it sufficiently broad so as to impose upon the corporate defendant bailee a duty to inform its bailors that their goods were uninsured? In his seminal work on the moral basis of tort liability Francis $\mathrm{H}$. Bohlen has pointed out that in none of the special relations "is one party made the guardian of the general well being of the other." 14 He illustrated his point as follows: ${ }^{15}$

13. See for example Fleming, The Law of Torts, 141 (4th ed. 1971).

14. Bohlen, The Moral Duty to Aid Others as a Basis of Tort Liability (1908) 56 U. Pa. L. Rev, 217.

15. Id. at $234-235$. 
Even a carrier owes no duty to its passenger to protect him from all injuries or to remove him from every perilous situation into which he may fall while enroute, nor to care for him if injured by a cause unconnected with the means of transportation.

... A striking instance of this principle is the divergent liability for the loss of a passenger's baggage turned over to the company's exclusive care, where its liability is practically that of insurer, and for the loss of baggage retained in the passenger's personal custody, which attaches only where some defect in the company's plant or operations has caused injury to it. So, it has been held that a railroad company is not bound to stop its train to recover a bag of jewels retained in a passenger's custody which falls from a window of its car without fault on its part.

As well, a bailee, unless under a contractual obligation to do so, is not duty bound to insure his bailor's goods. ${ }^{16}$ The exact limits of the duty of affirmative care imposed upon bailees are rather vague and therefore difficult to describe with precision. Though the scope of this paper does not permit this writer to attempt to characterize these outer limits, it is submitted that the duty of affirmative care generated by the relationship of bailment is limited to care that must be exercised in respect of the bailed chattel itself. The scope of the bailee's duty of affirmative care does not extend so far as to require all bailees to warn their bailors of the lack of insurance. McKenzie J. seemed to share this view. His reasons for judgment clearly imply that the corporate defendant's duty to inform did not arise from the general relationship of bailment which existed between it and the plaintiffs. Rather, the duty to inform arose from the special and unique relationship of the parties and the peculiar circumstances of the case which fostered in the plaintiffs' minds the mistaken belief that they were fully insured against all risks. The introductory words of what is perhaps the most crucial sentence in the entire judgment affirm that the duty to inform is limited to the unusual circumstances of this case: ${ }^{17}$

In the singular circumstances which prevailed here I hold that the plaintiffs' passive assumptions were reasonably held and that they were lulled into a false belief that the defendant would respond in the event of any loss by making good the damage, and that they left the whole matter of protection, including fire insurance, in his hands. [emphasis mine]

Therefore, it is submitted that warehousemen are not generally burdened by a duty to inform their bailors that bailed goods are uninsured. No doubt passing on this information is a common and desirable business practice, but in law this practice stems from courtesy rather than obligation.

Was the relationship of the parties special in a sense that would justify the imposition upon the corporate defendants of that affirmative duty of care which formed the basis of its liability? Because the class of special relations is not closed, it was unnecessary for the plaintiffs to bring their relationship with the corporate defendant within a category that the law had previously acknowledged as giving rise to duties of affirmative care. That the class of these special relations is expanding has been pointed out by various learned writers. ${ }^{18}$ What are the hallmarks of these special relations? Unfortunately, the cases have not as yet delineated the common denominators which link together the disparate categories of these relations. However, Bohlen and others have attempted, in an ex post facto manner, to rationalize the special relation cases.19 What

16. Morden v. Adamson (1977) 2 C.C.L.T. 45 (Ont. C.A.).

17. Supra, n. 1 C.C.L.T. at 133, W.W.R. at 749-750.

18. See Prosser, Law of Torts 339-342 (4th ed. 1971); and Linden, Canadian Negligence Law 221 (1972).

19. Bohlen, The Moral Duty to Aid Others as a Basis of Tort Liability (1908) 56 U. Pa. L. Rev. 217; McNiece and Thorton, Affirmative Duties in Tort (1949) 58 Yale LJ. 1272; and Fleming, The Law of Torts, 143 (4th ed. 1971). 
common threads did Bohlen perceive to be running through the various categories of special relations? In the first place, there is usually a benefit which enures to the advantage of the person burdened with the duty of care (the obligor). It is this benefit-in most cases an economic advantage-which justifies the imposition of a duty of affirmative care. ${ }^{20}$ Secondly, the relationship must in some respect be protective. Bohlen has suggested that the protective relationship must be founded upon:21

(1) the obligor's ability to protect the obligee's interests;

(2) the obligee's inability to protect his own interest; and

(3) the consequent reliance and dependence of the obligee upon the obligor's help.

As to the requirement of benefit, clearly the corporate defendant bailee received an economic advantage from its association with the plaintiff bailors. It is with respect to the second characteristic of these special relations that the nonfeasance theory of the case runs into difficulty.

The first requirement-that the obligor be capable of protecting the obligee-is probably satisfied. The corporate defendant could have warned the plaintiffs of the lack of insurance and could have insured the plaintiffs' goods against the risk of fire for their full value. In fact, Banman left the plaintiffs with the impression that the latter had been done. Fleming suggests that the duty of affirmative care is imposed upon the obligor because he is in a position of "peculiar vantage" with respect to protecting the obligee's interest.22 It is unclear whether this unique ability to protect modifies the requirement that the obligor be able to protect his obligee's interest. It may merely describe the usual position of obligors in respect to those relations which have previously been recognized as special. This writer would suggest that it is merely descriptive because, ultimately, the special relation category is designed to protect the reliance interest of the obligee who has good reason to expect that protective care will be extended to him by his obligor and acts, to his detriment, upon this expectation. While the "peculiar vantage" of the obligor to protect the obligee is a factor contributing to the obligee's reliance on that protection, the absence of this factor does not preclude that reliance from reasonably arising.

The second requirement-that the obligee be incapable of protecting his own interest-poses a more serious problem. Bohlen suggests that the obligee must be in a position of "helpless inability".23 Furthermore, he points out that this inability must arise from the very nature of the relationship between the obligor and obligee. ${ }^{24}$ Because the term "helpless inability" is not a term of art, it is difficult to be confident of its meaning. Nonetheless, to suggest that the plaintiff bailors were incapable of protecting themselves may be stretching even a liberal interpretation of Bohlen's statement of the law beyond its limits. The plaintiffs were in as good a position as the corporate defendant to protect themselves by taking out insurance. They had the power to protect themselves, though admittedly, they laboured under a mistaken belief, induced by Banman, that they were fully insured. Certainly their inability to protect

20. Linden, Canadian Negligence Law, 222 (1972); Prosser, Law of Torts 339 (4th ed. 1971); McNiece and Thorton, Affirmative Duties in Tort (1949) 58 Yale L.J. 1272.

21. Supra, n. 14 at $231-233$.

22. Supra, n. 13 at 143.

23. Supra, n. 14 at 232.

24. Id. at 233. 
themselves cannot be said to be helpless in the same sense as the inability of a passenger of a motor vehicle to protect himself or the inability of a bailor of goods bailed with a carrier to protect his goods.

It may also be suggested that even if the plaintiffs satisfied the requirement of "helpless inability", this inability did not arise from the very nature of their relationship with the corporate defendant. On the other hand, the nature of the relationship of the parties was, in part, defined by the representations made by Banman to the plaintiffs which led them to believe that their goods were insured, a belief which reduced the likelihood of their insuring their goods to nil, rendering illusory any ability on their part to protect themselves. Undoubtedly, in the absence of these representations, the relationship of the parties was not sufficiently special so as to justify the imposition upon the corporate defendant that affirmative duty of care which formed the basis of its liability. In the absence of the representations, the plaintiffs and Banman were simply parties to a commercial transaction who also happened to be friends. Surely this fact does not alter their legal obligations to one another. As well, the mere fact that the plaintiffs' business expectations were coloured by their friendship with Banman, in the absence of an express agreement, tacit understanding or representation, does not alter their legal obligations.

Assuming that Bohlen's first and second requirements were satisfied, it follows that his third requirement-that the obligee rely upon the obligor for protection as a consequence of the obligor's ability to protect him and his inability to protect himself-was satisfied as well. The plaintiffs did in fact rely on the protective care of the corporate defendant. The corporate defendant had the ability to protect the plaintiffs and the plaintiffs genuinely believed that it had exercised its protective ability by placing insurance against the risk of fire. This belief, which arose from the nature of the plaintiffs' relationship with Banman and from representations made to them by him, was the source of both their inability to protect themselves and their reliance on the corporate defendant.

On the basis of the preceding, is it possible to rationalize McKenzie J.'s decision as one in which the special relation of the parties gave rise to the duty of affirmative care? It is submitted that notwithstanding that the special relation requirements set out by Bohlen may not all have been satisfied, the special relation theory of this case is tenable. If it is correct to say, as has been suggested in this comment, that the special relation category is designed to protect the reasonably formed reliance interest of an obligee, this theory of the case is indeed credible. Banman, through his representations, assumed a posture of protective care in respect of the plaintiffs' interests; the plaintiffs reasonably believed that they were beneficiaries of this care ${ }^{25}$ and ultimately relied to their detriment on its being there.

On the other hand, it may well be the case that the law is much more restrictive in its approach. It may only be prepared to find a special relation, and thereby impose what is generally regarded as a burden in the form of a duty of affirmative care, if the obligee is powerless to protect

25. In suggesting that the plaintiffs reasonably believed that they were beneficiaries of this care, this writer is expressing what he believes to be McKenzie J.'s view: a view which he does not share. See pp. $28-30$ of this comment. 
himself and must, of necessity, rely on the obligor's protective care. ${ }^{26}$ In the instant case, though the plaintiffs' reliance on the corporate defendant may have been reasonable, it cannot be said to have risen from necessity. The plaintiffs were as capable as the defendant of protecting their interests.

\section{THE MISFEASANCE THEORY OF THE CASE}

This comment has thus far emphasized the nonfeasance theory of this case, not because this writer believes it to be the only tenable theory, but rather, because the language used by McKenzie J. opens the door for the case to be viewed as one in which liability was visited upon the corporate defendant because of its failure to take affirmative steps to protect the plaintiffs. It is submitted that there is one other theory which rationalizes McKenzie J.'s decision. The basis of this theory is that the corporate defendant's liability in negligence resulted from its positive acts of negligence and not from its failure to take affirmative action. In other words, the corporate defendant's liability resulted from its misfeasance and not its nonfeasance.

Many commentators have noted that what may superficially look like a failure to act, upon careful analysis, turns out to be active misconduct. Both Linden and Fleming in their texts provide illustrations of these cases of "pseudo-nonfeasance". ${ }^{27}$ Fleming has observed that:28

[t]he borderline between active misconduct and passive inaction has never been easy to draw ... . An engine-driver's failure to turn off steam in time to prevent a collision is not an example of supine inaction: an omission is involved but it is merely the element which makes his active conduct-driving-negligent. So, creating a situation of peril, however blamelessly, generates a consequential duty to adopt precautions before it culminates in injury, like warning approaching traffic after breaking down just below the crest of a hill ... [emphasis mine]

In other words, if a person, by his actions, creates a risk of harm to person or property, he has a duty to take corrective action before that harm eventuates. However, in cases where a person fails to take corrective action and the potential harm materializes, this does not necessarily mean that negligence lies in the failure to take corrective action. In Hedley Byrne \& Co. Ltd. v. Heller \& Partners Ltd.29 it will be recalled that the defendant's potential liability in negligence arose from its negligent misrepresentation of the credit-worthiness of a particular company and not from its failure thereafter to take corrective action by informing the plaintiff, before it acted on the advice, that the company in question was a poor credit risk. The original advice given by the defendant to the plaintiff, through an intermediary, created a risk of harm because in the circumstances of Hedley Byrne it was reasonable for the plaintiff to rely and act upon this advice to its financial detriment. Having created the risk of harm, the defendant was duty-bound to take corrective action by informing the plaintiff of the true state of affairs. In the absence of other factors, the House of Lords was prepared to impose liability on the defendant for its negligent mis-statement. There was no

26. A literal interpretation of Bohlen's three requirements leads one to this rather restrictive conclusion.

27. See Fleming's, The Law of Torts 141 (4th ed. 1971) and Linden's, Canadian Negligence Law 222-223 (1972); see also McNiece and Thorton's, Affirmative Duties in Tort (1949) 58 Yale L.J. 1271 where the label of "pseudo-nonfeasance" is adopted.

28. Supre, n. 13 at 141.

29. Supra, n. 2. 
suggestion that liability might have been founded upon its failure to correct the mistaken impression that it had left with the plaintiffs.

Similarly, in respect to the case at bar, it is submitted that the corporate defendant's negligence was founded not on its failure to inform the plaintiffs that their goods were uninsured, but on its misrepresentation of the state of the plaintiffs' insurance coverage. This view of the case raises two important issues for discussion. First, was there in fact a misrepresentation, and secondly, if so, can it fairly be described as negligent?

It will be recalled that McKenzie J. found that Banman's discussions with the plaintiffs left the plaintiffs with the false impression that they were fully insured against all risks. Furthermore, having regard to the general circumstances of the case and in particular the unique relationship that had developed between the parties, McKenzie J. found that the plaintiffs' mistaken belief was reasonably held. It was the misleading nature of Banman's words and conduct that rendered his statements to the plaintiffs mis-statements. ${ }^{29 a}$ When the plaintiffs Masons' television set was damaged, Banman told them that there was insurance covering the loss. That Banman actually intended, by his statement, to indicate that the corporate defendant's liability policy would cover the damage to the television set and did not intend to imply that the plaintiffs were protected by risk coverage was of no consequence. Implicit in McKenzie J.'s judgment is that the test of whether a statement is a misstatement is somewhat objective and not subjective as it is where the action is framed in deceit. ${ }^{30}$ It is not the meaning that the maker of a statement intends to convey that determines whether or not it is a misstatement, but rather the meaning that would be conveyed to a reasonable person in the same circumstances as the person to whom the statement is made. Because the plaintiffs believed that they were fully insured and because McKenzie J. found this belief to be reasonably held, ${ }^{31}$ Banman's statement was, in law, a mis-statement. While McKenzie J.'s judgment was not completely explicit on this point, he appeared to be treating this as one of those unfortunate cases where the defendant said too little and conveyed too much.

Banman's mis-statement was not negligent in the same sense as the mis-statement in the case of Hedley Byrne v. Heller where the defendant failed to act with reasonable care and skill in forming its opinion of the credit-worthiness of a prospective client of the plaintiff. Whereas in Hedley Byrne the defendant's opinion, albeit one formed without the proper care, skill and judgment that the situation called for, was accurately transmitted to the plaintiff, Banman's message was inaccurately and negligently transmitted. In other words, the corporate defendant's negligence was comprised of saying something true in a misleading way, i.e., in a way likely to mislead an ordinary man in the plaintiff's circumstances into believing that his goods were covered by insurance.

Whether Banman's general conduct and statements were sufficiently misleading as to warrant a finding of negligence is a matter of opinion. One might well be critical of the view that the plaintiffs' false belief, that

29a.Supra, n. 13 at 554 and cases cited therein.

30. See Akerhielm v. De Mare [1959] A.C. 789.

31. This writer does not agree with the learned trial judge's assessment that the plaintiffs' belief was reasonably held. The reasons for this disagreement will be made apparent shortly. 
they were insured, was reasonably held. It might be said that the plaintiffs 'jumped' to this conclusion and that there was nothing in Banman's statements which could justify the plaintiffs holding this belief. It is submitted that there are a number of reasons why Banman's suggestion, that he arrange "everything" from his end, could not reasonably have provided a basis for such a belief. In the first place, Banman's statement was merely a suggestion made prior to the plaintiffs' decision to use the corporate defendant's services. It was not a representation, or for that matter, an undertaking. At best, it could be viewed as an offer. Secondly, the offer seems to have been made in rather vague terms. Since at the time the offer was made the parties were at arm's length, it would have been unreasonable for the plaintiffs to construe the offer literally as including extraordinary, comprehensive, and protective care. Furthermore, the plaintiffs did not take up the defendant's offer. McKenzie J. considered this last point in his reasons for judgment. After noting that Banman offered to arrange everything from his end, he expressed the following view: ${ }^{32}$

For unexplained reasons neither of the plaintiffs followed this advice and each acted independently of it. Nevertheless despite this partial rejection of services offered by ... [Banman], they did decide to use him for storage.

This seems to imply that it was only in respect to moving their goods to storage that the plaintiffs rejected the defendant's offer that they put themselves entirely in his hands.

The second of Banman's statements which led the plaintiffs to mistakenly believe that their goods were insured, was his statement that there was insurance to cover the damage to the Masons' television set. Implicit in McKenzie J.'s judgment is that Banman should have appreciated the risk of transmitting this misleading impression; or, from another perspective, the plaintiffs' mistaken belief was reasonably held. This writer does not agree with these conclusions. While this is, admittedly, a matter of judgment, it is suggested that Banman's statement, in itself, was not sufficiently explicit to warrant such a-farreaching conclusion. Marlene Thompson v. Donald Sharpe $e^{33}$ is an analogous case in which Arnup J.A. takes the opposite view to that taken by McKenzie J. in the instant case. In that case the plaintiffs instituted an action against the defendant when they were injured by a wheel that came off a tractor being towed by the defendant's pick-up truck. The defendant's insurance agent was added to the action as a third party on the basis that it had represented to the defendant that he was fully protected and covered for all liability respecting the operation of his pickup truck and any attached vehicles. The insurance agent had previously advised the defendant that his policy would cover him for public liability in respect to any damage caused by any stock-car that he might tow so long as the stock-car did not come loose. Arnup J.A. dismissed the defendant's claim against his agent on the basis that the defendant's belief, that towing his farm tractor gave rise to the same legal results as towing a stock-car, did not flow "naturally and reasonably" from his agent's statement: ${ }^{34}$

It might well be that because of the representation . . . the defendant believed that the same representation applied to the farm tractor being towed, but his belief does not

32 Supra, n. 1 C.C.L.T. at 132, W.W.R. at 749.

33. (1977) 2 C.C.L.T. 134 (Ont. S.C.).

34. Id. at 141 . 
make the Agency liable unless such belief flowed naturally and reasonably from the representation about the towing of a stock car. I do not think it did. . . [Towing] a farm tractor does not give rise to the same legal results as towing a stock car.

It is submitted that Arnup J.A.'s reasoning applies equally well to the case under discussion and that his views are to be preferred over those of McKenzie J. The mere fact that insurance covered the damage to the plaintiffs' television set did not necessarily mean that the plaintiffs' goods were insured against the risk of fire. Though the opposite conclusion is one which persons uninitiated with various types of insurance policies would frequently arrive at, this commentator is of the opinion that their belief could not be said to flow naturally and reasonably from the representation about the television set. This view of the case puts the corporate defendant in the unfortunate position of being the victim of the plaintiffs' unreasonable misconception.

On the other hand, it is all too easy to be critical, in borderline cases such as this, of matters of judgment. It is incumbent upon commentators to be cognizant of the difficulties involved in making a determination of negligence without the benefit of being privy to the actual proceedings themselves. Having regard to the circumstances of the case it may be that McKenzie J.'s view that the defendant lulled the plaintiffs into a false sense of security was correct.

In the result, assuming McKenzie J. was correct in finding Banman to be negligent, the defendant's liability was founded on negligent misstatement. Banman created the risk of harm that eventually materialized: namely, that the plaintiffs would be uninsured when their goods were destroyed. Having created the risk of harm, the corporate defendant was under a duty to take corrective action by informing the plaintiffs of their lack of insurance. The corporate defendant's failure to take corrective action prior to the plaintiffs' goods being destroyed, however, was not the source of its negligence. The source of its negligence was the misleading impression generated by Banman through his mis-statements. In other words, the corporate defendant's negligence lay in the positive acts of its agent, its misfeasance, rather than in its failure to take affirmative corrective action, its nonfeasance.

\section{THE NATURE OF THE PLAINTIFFS' LOSS AND ITS IMPLICATIONS}

The theoretical problem in this case relates to the nature of the loss suffered by the plaintiffs and the ability to recover this type of loss in a conventional negligence action. It is submitted that the plaintiffs' loss was purely economic. Though the plaintiffs' goods were in fact destroyed in the warehouse fire, the corporate defendant's negligence did not cause or contribute to this physical loss. It will be recalled that McKenzie J. found that the corporate defendant exercised due care in providing a safe storage facility and, as well, was not responsible for the act of its employee who set the fire. What loss was caused by the corporate defendant's negligence? McKenzie J. found that the corporate defendant's negligence resulted in the plaintiffs' failure to insure their goods and their consequent inability to collect insurance monies covering their loss. In other words, the defendant's negligence precluded the plaintiffs from obtaining financial compensation for their physical loss. Clearly, this is a case of purely economic loss, although admittedly it is camouflaged by the physical loss. Not only was the physical loss the sine qua non of the 
economic loss, but the value of the physical loss presumably would represent the value of the financial loss.

That purely economic loss has not been recoverable simply on the basis of satisfying the standard test of "reasonable foreseeability" has been well documented. The reasons for this have also been well documented.35 The most important of these reasons is that the test of reasonable foreseeability has been considered "an inadequate restricting device" 36 in an area where there is potential for "liability in an indeterminate amount, to an indeterminate class for an indeterminate time".37 While the scope for recoverability of purely economic loss has been widening, recovery still seems to be the exception rather than the rule. ${ }^{38}$ In light of the law's rather restrictive approach to claims for purely economic loss it is odd that Mr. Justice McKenzie's reasons for judgment make no mention of the nature of the plaintiffs' loss. Is it possible that he regarded the case as one involving physical rather than purely economic loss? Having regard to the hidden character of the purely economic loss in the case one must consider this as a possibility.

Are there any other explanations of the plaintiffs' recovery of their economic loss? Could it be that McKenzie J. was aware of the character of the plaintiffs' loss and placed it on the same footing as physical loss? It was certainly open for McKenzie J. to take this bold but not unprecedented step. In Ministry of Housing \& Local Government v. Sharp, ${ }^{39}$ Salmon L.J. stated in dictum that: 40

[8]o far, however, as the law of negligence relating to civil actions is concerned, the existence of a duty to take reasonable care no longer depends on whether it is physical injury or financial loss which can reasonably be foreseen as a result of a failure to take such care.

This dictum was approved in the Supreme Court by Mr. Justice Ritchie in Rivtow Marine Ltd. v. Washington Iron Works. ${ }^{41}$ However, some writers were of the opinion that this approval was limited to cases of products liability of which Rivtow Marine was merely an example. ${ }^{42}$ In MacMillan Bloedel Ltd. v. Foundation Co. of Canada, Ltd., ${ }^{43}$ Legg J., noting that Salmon L.J.'s dictum was referred to and approved by Mr. Justice Ritchie in Rivtow Marine, stated that he was prepared to follow it. ${ }^{44}$ It is not without interest that MacMillan Bloedel was not a products liability case. McKenzie J., therefore, had at his disposal a dictum which originated in the English Court of Appeal, and was approved by both his own Court, the British Columbia Supreme Court, and the Supreme Court of Canada, indicating a willingness to challenge what Fleming has called "the facile premise that the law of negligence ... [is] opposed to all claims for purely economic loss".45 However, there is nothing in McKenzie J.'s judgment which suggests that in his view purely economic and physical loss are recoverable on the same footing. Surely in light of the stage of

35. See Linden's, Canadian Negligence Law 322-324 (1972).

36. L. N. Klar's annotation of MacMillan Bloedel Ltd. v. Foundation Co. of Canada Ltd. (1977) 1 C.C.L.T. 358 at 359 (B.C.S.C.).

37. Ultramares v. Touche Niven \& Co. (1931), 255 N.Y.S. 170 at 179, 174 N.E. 441 at 444 per Cardozo J.

38. Supra, n. 36 at $358-362$.

39. [1970] 2 Q.B. 223 (C.A.), [1970] 1 All E.R. 1009.

40. Id. Q.B. at 278, All E.R. at 1027.

41. [1974] S.C.R. 1189 at 1215, [1973] 6 W.W.R. 692 at 711, (1974) 40 D.L.R. (3d) 530 at 547.

42. See, for example, Klar, supra, n. 36.

43. (1977) 1 C.C.L.T. 358 (B.C.S.C.).

44. Id. at 367.

45. Supra, n. 13 at 165. 
development of the law relating to purely economic loss, McKenzie J. would not have been so casual as to proceed on the assumption that both types of loss are recoverable on the same basis. It is not intended by the preceding discussion to suggest that tort law is ready to totally abandon its reluctance to allow recovery for pecuniary loss. The widespread fear that too heavy and unpredictable a burden on commerce and other activities would flow from treating economic loss exactly like physical injury would seem, at least for the immediate future, to preclude such a dramatic reversal of the law. ${ }^{46}$ The suggestion is that the time is ripe for tort law to establish more generous ground rules for the recovery of purely economic loss. Precisely what form these ground rules will take and where the line will be drawn, to protect the economic sphere from the burden of inordinate and massive liability, is impossible to say with certainty.

Was there another avenue of reasoning open to McKenzie J. that could possibly have justified the plaintiffs' success? It is submitted that it was open to McKenzie J. to treat the case as coming within the scope of a recognized exception to the rule precluding recovery for purely economic loss. The suggestion is that the law's reluctance to award compensation for purely economic loss is limited to claims based upon a Donoghue v. Stevenson ${ }^{47}$ neighbourly duty of care. Where there is a duty of care that arises from a special relation, as there is, for example, in cases of a Hedley Byrne genesis, the law is prepared to relax its restrictive approach. This is the case whether the special relation gives rise to a duty to refrain from active misconduct as it did in Hedley Byrne v. Heller or gives rise to a duty to take affirmative care as it did in Rivtow Marine Ltd. v. Washington Iron Works et al.48 In short, where a special relation gives rise to a duty of care which is breached the law will compensate for purely economic loss whether the defendant is guilty of misfeasance or nonfeasance. ${ }^{49}$

\section{THE APPLICABILITY OF HEDLEY BYRNE v. HELLER}

Having regard to the various elements of the case, Banman's negligent misrepresentation, the plaintiffs' purely economic loss, and the unique business relationship of the parties, the plaintiffs' success might well have been justified by the decision in Hedley Byrne v. Heller. Prior to the decision neither law nor equity, in the absence of a contract or a fiduciary relationship, ${ }^{50}$ furnished a remedy to the victims of negligent mis-

46. See Fleming's, The Law of Torts 164 (4th ed. 1971) and Linden's, Canadian Negligence Law 323 (1972).

47. [1932] A.C. 562.

48. Supra, n. 41. In this case the corporate defendants' liability for the plaintiff's purely economic loss was grounded on their failure to warn the plaintiff of certain structural defects in a logging crane which one had manufactured and the other distributed. The plaintiff suffered economic loss when the discovery of the defect made it necessary to repair the crane during its busiest period of use. A timely warning would have permitted repairs to be made during a less busy period. It will be noticed that liability of the corporate defendants in both Rivtow Marine and Mason v. Morrow was based upon their failure to warn. In Rivtow Marine Mr. Justice Ritchie was unequivocal about the source of this duty of affirmative care. He expressly stated that the source of this duty of care was not the neighbour concept of Donohue v. Stevenson (S.C.R. at 1208; W.W.R. at 705; D.L.R. at 542) but rather the "proximity of relationship" of the parties (S.C.R. at 1215; W.W.R. at 711; D.L.R. at 547). Though Ritchie J. did not actually describe the relationship of the parties as special, it is submitted that, the factors which gave rise to the Bo-called "proximity of relationship" were those which are characteristic of special relations.

49. It would make little sense to suggest that the special relation of the partieg imposed upon the corporate defendant a duty to warn and then conclude that the purely economic nature of the plaintiffa' loss precluded them from successfully suing for breach of this duty. Such a conclusion would render illusory the corporate defendant's duty of care because the only risk that is created by the failure to warn is a risk of economic loss. On this view the corporate defendant's failure to carry out its duty could never result in liability.

50. It is unlikely that the humble commercial relationship of the parties, even as modified by their personal friendship, could be considered to be of a sufficiently intense fiduciary character so as to support the equitable action for negligent misrepresentation firat recognized in Nocton v. Lord Ashburton [1914] A.C. 932. See Sealey, Fiduciary Relationships [1962] C.L.J. 69 and Sealey, Some Principles of Fiduciary Oblizations [1963] C.LJ. 119. 
statements. The only duty imposed upon a person transmitting factual information or giving advice was not to deliberately mislead his advisee. Neither law nor equity required of an advisor that he form his opinion or search out his facts carefully or that he transmit his message carefully. In short, there was a duty of "common honesty but not of care . . ."51 In 1963 the House of Lords in Hedley Byrne recognized the existence of a duty of care. In what circumstances does this duty arise?

Though the various Law Lords formulated these circumstances in different ways, it seems to be generally accepted that the effect of their language amounted to the same thing. ${ }^{52}$ Fridman has summarized the circumstances as follows: ${ }^{53}$

[w] hat the House of Lords had in mind in the Hedley Byrne case were situations in which one person gratuitously, but otherwise for good reasons, seriously undertook, expressly or by implication, the obligation of providing information or advice to another, at the other's request. The circumstances must be such that the former knew or should have known . . . that the latter was going to rely on the information or advice for the purpose of some action of his own, and might therefore come to some harm if it were inaccurate or misleading.

Other commentators have summarized these circumstances in different terms. Fleming has said that the duty of care arises when a person takes it upon himself "to supply information or advice, directly or through an intermediary, to someone who, as they know or should know will place reliance on it to his financial detriment."54 Linden has been even more general in summarizing the circumstances in which the duty to not mislead arises: 55

[w] hat is now needed is a situation where (1) the person who gives the information realizes that the other is relying on its accuracy, and (2) the person who receives the communication acts reasonably in relying upon it.

It is submitted that what is at the heart of these formulations and the more elaborate and restrictive formulations of those Law Lords who participated in the decision in Hedley Byrne is that the duty to take care to not mislead arises when it is reasonably foreseeable that the person or a limited class of persons to whom a statement is ultimately directed would reasonably place reliance on it to his or their detriment. The apparently more restrictive and cautious formulations of the duty situation merely detail the factual situations in which it is reasonably foreseeable that reasonable reliance will be placed on a representation. For example, it has been repeatedly pointed out that the duty of care arising out of Hedley Byrne is limited to situations where a misrepresentation is made in a serious communication. The duty to not mislead will not arise when a misrepresentation is made casually in a social or other informal, non-professional or non-business setting. This is hardly surprising. It is not reasonably foreseeable that reasonable reliance will be placed upon a representation made in such circumstances. In other words, the serious communication requirement springs directly from the more general requirement that it be reasonably foreseeable that reasonable reliance will be placed on the representation.

Fleming and others have pointed out that the duty to take care to not

51. Supra, n. 13 at 563 .

52. Fridman, Negligent Misrepresentation (1976) 22 McGill Law Journal 1.

53. Id. at 6-7.

54. Supra, n. 15 at 160 .

55. Supra, n. 35 at 341. 
mislead does not arise from an "open-ended formula of foreseeability."56 However, this does not negate the view that foreseeability is the touchstone of the existence of such a duty. It merely reflects a limitation placed upon the operation of the test of foreseeability-a limitation generated by the fear of imposing "liability in an indeterminate amount for an indeterminate time to an indeterminate class." 57 This limitation manifests itself in the limited class of persons protected by the Hedley Byrne principle. That class is not comprised of all those whom the defendant could foresee would place reasonable reliance on his statement but only those individuals or members of a limited class ${ }^{58}$ to whom information or advice is passed either directly or through an intermediary.

When a representation is made to a member of the protected class which invites "justifiable reliance", 59 the duty of care to not mislead is imposed upon the maker of that representation. When will reliance on a statement be justifiable? It is submitted that the very circumstances which make reliance on a statement justifiable, make it reasonably foreseeable that such reliance will be placed on that statement. Assuming that it is correct to characterize Banman's statements as representing to the plaintiffs that they were insured against all risks, it was not unreasonable for the plaintiffs to rely on these statements. On the contrary, it was reasonable to expect that the plaintiffs, upon being told by their warehouseman and friend, Banman, that their goods were fully insured, ${ }^{60}$ would refrain from taking steps to protect themselves. Though Banman was unaware that the plaintiffs had construed his various statements so as to believe that they were fully insured, the corporate defendant's liability in negligence necessarily implies that McKenzie J. was of the view that Banman should have appreciated the risk of this construction and its inevitable consequences. Therefore, it is submitted that the basic notion which underlies the imposition of liability in negligent misstatement cases-protection of a reasonably formed and reasonably foreseeable reliance interest-is present in this case and could well have been utilized to anchor the corporate defendant's liability.

Is there an additional notion which underlies the Hedley Byrne principal? C. Harvey, whose article "Economic Losses and Negligence"61 has been of considerable interest and use to the judiciary, including the Supreme Court of Canada, ${ }^{62}$ would add that liability for economic loss flowing from a negligent statement is premised upon an assumption of responsibility by the maker of the statement for damage caused by it. He states: 63

... a person should be bound by a legal duty of care to avoid causing economic loss to another in circumstances where a reasonable man in the position of the defendant would foresee that kind of loss and would assume responsibility for it. [emphasis mine]

56. Supra, n. 13 at 564 .

57. Supra, n. 37.

58. Haig v. Bamford, Hagan, Wicker, Gibson [1976] 3 W.W.R. 331, (1977) 72 D.L.R. 68.

59. Supra, n. 13 at 564 .

60. Though Banman did not actually suggest that the plaintiffs were fully covered, in law the corporate defendant's agent is taken to have said that very thing. See p. 28 of the text of this comment.

61. (1972) 50 Can. Bar Rev. F, 0 .

62 Harvey's article has been referred to in the following cases: Haig v. Bamford et al. [1976] 3 W.W.R. 331 at 341 (S.C.C.), (1977) 72 D.LR. 68 at 77; Rivtow Marine Ltd. v. Washington Iron Works (1970) 74 W.W.R. 110 at 120 121 (B.C.S.C.) and Star Village Tavern v. Neild et al. (1977) 71 D.L.R. (3d) 439 at $440-441$ (Man. Q.B.).

63. Supra, n. 61 at 600 . 
Fleming too has noted the defendant's assumption of responsibility for what he says is the "sheet anchor"64 of the Hedley Byrne duty of care. When does a defendant in a negligent mis-statement case assume responsibility for what he says? Certainly it is not necessary to prove that he has consciously accepted a notion of accountability for the consequences of his words. Rather, according to Harvey, what must be proved is that the "reasonable man in the shoes of the defendant would have assumed responsibility for the loss." 65 In the recent case of Star Village Tavern v. Neild et al.,66 Hamilton J. paraphrased Harvey's test in the following terms: 67

To do what Harvey suggests, ... . the Judge should say to himself-if I were this defendant, being a reasonable man, freed from the prejudice of self-interest, would $I$ in these circumstances feel a financial obligation to this plaintiff as a result of my negligence?

It is submitted that in negligent mis-statement cases such an obligation would be felt if, and only if, it was reasonably foreseeable that reasonable reliance would be placed on the defendant's statements. Surely no other conclusion is acceptable in a tort system where only exceptionally is fault not the basis of liability.

Does this mean that the assumption of responsibility requirement is merely a guise for the reasonable foreseeability requirement? The answer is no. No doubt the former requirement includes the latter ${ }^{68}$ but it is suggested that it encompasses wider and distinct considerations. The assumption of responsibility requirement goes further than the reasonable foreseeability formula by inquiring into whether there are policy reasons which necessitate a decision adverse to the plaintiffs' interests. This seems to be Dickson J.'s view of the operation and scope of the test of "assumption of responsibility". In Haig v. Bamford he stated:69

[the 'assumption of responsibility' test] would allow the Court to narrow the scope of liability from that resulting from a foreseeability test, but it would . . . require a policy determination as to what should be the scope of liability. As Lord Pearce stated in Hedley Byrne (p. 615):

How wide the sphere of duty of care in negligence is to be laid depends ultimately on the court's assessment of the demands of society for the protection from the carelessness of others. [emphasis mine]

The most important of the policy considerations limiting liability for economic loss arising from negligent mis-statement has been referred to previously in this comment. The fear of liability indeterminate in amount, time and class, limits the class of persons protected by the Hedley Byrne principle.

In light of the preceding, and once again assuming that it is correct to characterize Banman's statement as representing to the plaintiffs that they were insured against all risks, can it be said that the corporate defendant assumed responsibility for the losses caused by its agent's statement? It is intended to answer this question by examining some of the factors which the courts look to in determining whether they will

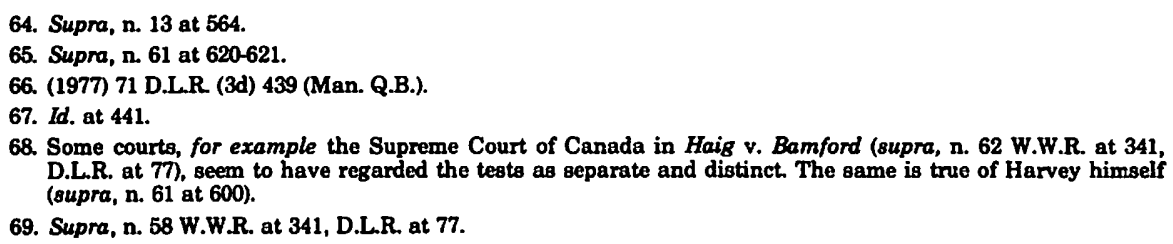


impute to the maker of a statement a "notional assumption of responsibility".70 Harvey's article lists seventeen factors which he suggests are relevant to the consideration of whether there has been an assumption of responsibility and hence a duty of care sufficient to support a claim for purely economic loss. ${ }^{71}$ Most of the factors listed, looked at in a Hedley Byrne context, are tied into the issue of whether it was reasonably foreseeable that reasonable reliance would be placed upon the defendant's information or advice. It is beyond the scope of this comment to examine each of these factors and apply them to the instant case. However, it is important to note that, as yet, there is no way of objectively determining precisely what combination of factors gives rise to the presence of a duty of care. This is as it should be. Objective formula tend to be applied rigidly with results that too often are capricious. None of these factors should be looked upon either individually or in combination as determinative of a duty of care or lack thereof. Rather, they should be looked upon as aids in assessing, first, whether on the particular facts under consideration it was reasonably foreseeable that reasonable reliance would be placed on the statement, and secondly, whether there is any policy reason to prevent the plaintiffs from succeeding despite satisfying the reasonable foreseeability test. These are matters of judgment which should not be obscured by or made secondary to "mechanical aids".

The controversial case of Mutual Life Assurance v. Evatt2 illustrates the danger of attaching too much importance to one of these factors. The case has been severely criticized by writers ${ }^{73}$ although, as Fridman points out, not as yet by the courts. ${ }^{74}$ In Evatt the Privy Council faced the familiar scenerio of a plaintiff who suffered financial loss because of his reliance on the careless investment advice of a defendant company. It was crucial to the decision of the Privy Council that the corporate defendant was an insurance company not in the habit of providing investment advice to outsiders. The reason the plaintiff sought the defendant company's advice was because the defendant company was associated with P. Ltd., a company in which the plaintiff considered investing, and therefore had access to complete and up-to-date information of the financial affairs of P. Ltd. As well, the defendant company had in its employ persons capable of making a reliable judgment as to the safety and desirability of the plaintiff's potential investment. On these facts, the Privy Council, over the strong dissent of Lords Reid and Morris, dismissed the plaintiff's action holding that the defendant owed no duty of care to the plaintiff other than that of not deliberately misleading him. Lord Diplock, speaking for the majority of the Council, suggested that liability for negligent mis-statement assumed:75

70. Supra, n. 61 at 604 .

71. Supra, n. 61 at 604-611. Nine of these factors, in the context of Hedley Byrne are particularly noteworthy: "(1) any special skill possessed by the defendant, (2) any undertaking to apply that skill for the benefit of the plaintiff which may be implied from such facts as the giving of advice on a subject included in the defendant's area of skill or expertise, (3) any ad hoc voluntary undertaking to do something carefully for the plaintiff's benefit, (4) the seriousness of the occasion, (5) knowledge on the defendant's part that reliance will be placed on his conduct [including imputed knowledge], (6) any express warranties given by the defendant. (7) any express terms "agreed" between the parties as to acceptance or disclaimer of responsibility, and (8) the reward if any which the defendant anticipates. . . (15) the defendant's ophere of business or professional expertise..."

72. [1971] A.C. 793, [1971] 1 All E.R. 150.

73. See Linden, supra, n. 35 at 335-337; Harvey, supra, n. 61 at 609 and H. J. Glasbeek, Negligent Misstatements in the Privy Council-Area of Liability Clearly Delimited (1972) 50 Can. Bar Rov. 580.

74. Supre, n. 52 at 7.

75. Supra, n. 71 A.C. at 807 , All E.R. at 159. 
... an ascertainable standard of skill, competence, and diligence with which the advisor is acquainted or had represented that he is. Unless he carries on the business or profession of giving advice of that kind he cannot be reasonably expected to know whether any and if so what degree of skill, competence or diligence is called for, and $a$ fortiori, in their Lordships' view, he cannot be reasonably held to have accepted the responsibility of conforming to a standard of skill, competence or diligence of which he is unaware, simply because he answers the enquiry with knowledge that the advisee intends to rely on his answers.

It is conceded that proof that advice relied on by the plaintiff was proferred by a defendant who was in the business or profession of supplying such advice is a relevant factor in determining whether it was reasonably foreseeable that such advice would reasonably be relied upon. However, as Harvey has stated: ${ }^{76}$

... as an overriding factor, as a condition precedent to liability it is open to criticism ... [I]t is not justifiable in principle: enough other relevent factors may be present in any one case to lead the court unavoidably to the conclusion that [the advice invited justifiable reliance].

This seems to have been the approach of Lords Reid and Morris who said: 77

In Hedley Byrne their Lordships were not laying down rules. They were developing a principle which flows, as all branches of the tort of negligence, from giving legal effect to what ordinary men habitually do in certain circumstances.

Though the plaintiffs could not have established that the defendant was, or held himself out to be, in the business of providing information as to insurance, perhaps it would have been sufficient to establish, as they could have, that the defendant in the course of his business routinely provided such information to his customers. This would seem to bring the plaintiffs' case outside the spirit of the Evatt exception, since the habitual proffering of such information would, or at least should have acquainted the defendant with whatever "standard of skill, competence and diligence" was required to proffer such information. The view that the habitual proffering of information in the course of the defendant's business gives rise to a Hedley Byrne duty of care conforms with the American Restatement of the Law of Torts ${ }^{78}$ requirement which was referred to by Lord Diplock in the following terms: ${ }^{79}$

... the maker of the statement ... [must] be a person who makes it a part of his business or profession to supply for the guidance of others in their business transactions information of the kind contained in the statement and that the statement should be made by him in the course of that business or profession.

Alternatively, it could be argued that the restrictive approach in the Evatt case was never meant to apply where no special standard of skill, competence, or diligence was required of the advisor in order for him to provide the information in question. The suggestion is that it makes little sense to apply Evatt to a case where the information sought is purely factual and the advisor is in a special position, when asked a specific question, of providing a reliable answer. This was recognized by Lord Herschell in Derry v. Peek ${ }^{80}$ when he suggested that the general rule that

76. Supra, n. 61 at 609 .

77. Supra, n. 71 A.C. 813, All E.R. 163.

78. (2nd) Vol. 3, p. 122, para. 552.

79. Supra, n. 71 A.C. 802 , All E.R. 154.

80. (1889) 14 App. Cas. 337. 
a person was only liable for his fraudulent misrepresentations did not apply to: ${ }^{81}$

... those cases where a person within whose special province it lay to know a particular fact has given an erroneous answer to an inquiry made with regard to it by a person desirous of ascertaining a fact for the purpose of determining his course.

When a bailor asks his bailee warehouseman whether or not his goods are insured, no exercise of skill or competence is required to answer this question. The answer is found in the knowledge which the bailee, and the bailee alone, is naturally in possession of.

This leads to the next question. Does the Hedley Byrne principle presuppose that the advisee request the information provided by the advisor? The answer is important because in the instant case the information which misled the plaintiffs into believing that they were insured may not have been specifically requested. The cases, while not providing a clear answer to this question, have formulated the principle on the premise that such a request must be involved. Fleming's conclusion that the duty of care is not limited to situations where information or advice is solicited, ${ }^{82}$ is supported by his suggestion that the tendency to presume that such a request must be involved is a natural outgrowth of formulating principles in cases where such requests have been made: 83

Hedley Byrne being concerned with requested information, it is understandable that some formulations in that case (e.g. Lord Reid's) were so limited. But others (e.g. Lords Hodson and Morris) were not.

Though one can conceive of circumstances in which unsolicited advice should raise a suspicion as to the reliability of that advice this does not apply to the plaintiffs' claim in the instant case. Whether a bailee informs his bailor that his goods are insured in response to a specific question or whether this information comes unsolicited would seem to make little difference. All other things being equal there is no reason to distrust the unsolicited information. It is submitted therefore, that a request for information or advice by an advisee is not a condition precedent to the imposition of liability for negligent mis-statement. The request for information or advice, or the lack of such a request, is merely a factor to be considered in determining the primary question of whether it was reasonably foreseeable that the advisee would reasonably rely on it to his detriment.

Are there any other impediments to the application of the Hedley Byrne principle to the case at bar? A potentially insuperable problem is posed by the existence of a contract between the parties. ${ }^{84}$ In J. Nunes Diamonds v. Dom. Elec., ${ }^{85}$ Pigeon J. speaking for a majority of the Supreme Court of Canada stated:86

81. Id. at 360 . But see Low v. Bouverie [1891] 3 Ch. 82, [1886-90] All E.R. Rep. 1 which can be distinguighed on the ground that the defendant in that case neither supplied the information sought in the course of his business, nor held himself out as being prepared to do so. See Lord Diplock's discussion of Low v. Bouverie in Evatt, supra, n. 71 A.C. at 805, All E.R. 157.

82. Supra, n. 13 at 567.

83. Id. at n. 21.

84. McKenzie J. paid little attention to the contractual basis of the plaintiffs' claim. He made no reference to it other than noting that the plaintiffs claimed in both contract and tort (supre, n. 1 C.C.L.T. at 122, W.W.R. at 738).

85. [1972] S.C.R. 769, 26 D.L.R. (3d) 699.

86. Id. S.C.R. at 777.778, D.L.R. at 727-728. 
[t] he basis of tort liability considered in Hedley Byrne is inapplicable to any case where the relationship between the parties is governed by contract, unless the negligence relied on can properly be considered as "an independent tort" unconnected with the performance of that contract.

It is submitted that in the case at bar the negligence complained of is an "independent tort" unconnected with the performance of the contract that subsisted between the parties. The contract in the case at bar imposed no obligation on the defendant except to take reasonable and proper care of those goods entrusted to it by the plaintiffs. Since the tort committed by the defendant did not relate in any respect to this obligation, by definition it is unconnected with the performance of the contract. In other words, the contract imposed upon the corporate defendant a duty to take care of goods. The negligence of the corporate defendant related to a breach of a totally unconnected duty-a duty to take care to not mislead the plaintiffs to their detriment. Since the contract between the parties was not intended to govern this latter obligation, the breach of this duty is an independent tort unconnected with the performance of the contract. ${ }^{87}$

The final obstacle to the successful application of Hedley Byrne to the case at bar may only be an obstacle for the plaintiff Fraser. This comment has previously noted that not every foreseeable plaintiff relying, even reasonably, on the misleading words of a defendant is entitled to enlist Hedley Byrne to his aid. The fear of a "burden of liability escalating into extravagance" 88 has restricted the class of foreseeable plaintiffs who are protected by the principle of Hedley Byrne. For the plaintiffs Mason, the limitation on the class of persons protected poses no problem. All of Banman's misleading statements were made directly to them. However, the plaintiff Fraser, apparently, was not party to the discussion relating to insurance coverage of the damaged television set. ${ }^{89}$

It may be that Mrs. Fraser was sufficiently misled by Banman's general conduct and other representations made directly to her so as to justify her being able to invoke Hedley Byrne. Assuming, however, that this is not the case, and further assuming that the Masons told her of the "television discussion", can it be argued that the misleading impression generated by that discussion is the source of a duty of care owed to her by the corporate defendant?

Only those plaintiffs who are provided with information by defendants who know or should know that they (the plaintiffs) will rely on this information are owed a duty of care. In most cases in which plaintiffs have successfully argued breach of a Hedley Byrne obligation the defendant has either directly or through an intermediary provided information to the plaintiff for the purpose of guiding that plaintiff's course of action. Banman did not furnish the information directly to Mrs. Fraser. Nor can it be said that the Masons were intermediaries for her.

87. Assuming that the corporate defendant's negligence cannot be considered an "independent tort" there is yet another possible exception to the rule that the existence of a contract precludes tortious liability from being imposed upon the parties to the contract. In Bagat v. Stevens Scanlon [1966] 1 Q.B. 197 at 204 Diplock LJ. declared that in specially recognized relationships, including that of bailor-bailee, a duty of care in tort might well co-exist with a duty of care under contract. Whether the scope of this exception is sufficiently broad so as to include a Hedley Byrne duty of care remains to be seen. However, it is submitted that the better view is that only that duty of care generated by the general relationship of bailment may co-exist with a contractual duty of care under the Bagot v. Stevens Scanlon exception. As has already been pointed out in this comment the duty of care which formed the basis of the corporate defendant's negligence did not arise from the general relationship of bailment.

88. Supra, n. 13 at 564 .

89. McKenzie J.'s reasons for judgment (supra, n. 1 C.C.I.T. at 127-128, W.W.R. at.744) indicate that only one of the Masons was involved in the "television discussions" with Banman. 
However, it might be said that Banman should have known that the Masons would communicate to Mrs. Fraser the text of the television discussion and that she would rely on the "natural and reasonable" conclusion that could be drawn from that conversation, i.e., that her goods were insured and that it was unnecessary for her to take steps to protect her pecuniary interest in them. ${ }^{90}$ In light of the recent Supreme Court of Canada decision in Haig v. Bamford ${ }^{91}$ this form of constructive knowledge might well be enough to support a Hedley Byrne duty of care.

In Haig v. Bamford the corporate defendant prepared audited financial statements for Company $\mathfrak{S}$. The corporate defendant knew that its statements would be passed on to a limited number of potential investors interested in Company $S$, but did not know the names of these investors. The statements were furnished to Company $\mathbf{S}$ who in turn distributed them to the various potential investors. Though the corporate defendant was aware of the use that its statements would be put to, it cannot be said that it directly provided information to the plaintiffs. Nor can it be said that Company $\mathbf{S}$ was an intermediary through whom the corporate defendant provided information to the plaintiffs. On these facts, Dickson J., with whom the majority of the court concurred, considered three possible tests that might be applied to invoke a duty of care on the part of the corporate defendant vis-a-vis the third party plaintiffs: 92

(i) foreseeability of the use of the financial statement and the auditor's report thereon by the plaintiff and reliance thereon;

(ii) actual knowledge of the limited class that will use and rely on the statement;

(iii) actual knowledge of the specific plaintiff who will use and rely on the statement.

Ultimately the liability of the corporate defendant was founded upon the duty of care which resulted from the application of test (ii). Dickson $\mathrm{J}$. considered test (iii) "on the authorities ... too narrow." 93 Despite the rejection of test (iii) in the circumstances of Haig v. Bamford there seems little doubt that ordinarily its satisfaction gives rise to a duty of care. Dickson J. was not suggesting that test (iii) could never be appropriately utilized to found a Hedley Byrne duty of care. Rather his suggestion was that the more liberal test-test (ii)-was the "proper test to apply in . . . [the] case [before him]."94 Therefore, actual knowledge that a specific plaintiff will use and rely upon the statement of the defendant will ordinarily give rise to a duty of care. Though Banman did not have such actual knowledge it has been pointed out that perhaps he should have known that his statement would be transmitted to Mrs. Fraser who would likely rely on it and therefore refrain from taking steps to insure her goods.

Assuming that Banman neither knew nor should have known that Mrs. Fraser would learn of, rely on, and be misled by his statement, it may still be contended that it was reasonably foreseeable that these things should occur. However, it has been pointed out that the proximity of relationship between plaintiff and defendant required by the principle

90. Banman was apparently aware that the Masons were daughter and son-in-law of Mrs. Fraser and that they lived in the same apartment with her. Furthermore, Mrs. Fraser would naturally be interested in any developments relating to the storage of goods with the corporate defendant. It is an arguable point, therefore, that Banman should have known that the Masons would communicate to Mrs. Fraser the details of the television incident and the ensuing discussions.

91. Supra, n. 58, W.W.R. at 341, D.L.R. at 77.

92. Supra, n. 58, W.W.R. at 338, D.L.R. at 75 .

93. Id. W.W.R. at 339, D.L.R. at 75.

94. Id. 
of Hedley Byrne is more circumscribed than the test of reasonable foreseeability would indicate. On the other hand, various learned writers have suggested that the courts may eventually abandon their fears of indeterminate liability and extend Hedley Byrne to all reasonably foreseeable plaintiffs.95 In this regard it is interesting to note that Dickson J. in Haig v. Bamford considered and did not reject out of hand the test of foreseeability as the test for determining who may be a Hedley Byrne plaintiff. He avoided the issue by concluding that it was unnecessary for the purposes of the case before him to consider whether all reasonably foreseeable plaintiffs are protected by Hedley Byrne.96 Whether Dickson J.'s approach to the test of reasonable foreseeability merely reflects the tendency of the Canadian judiciary to consider only that law which is absolutely necessary to decide the case before it or whether it signals a developing attitude towards this relatively expansive test, remains to be seen.

\section{CONCLUSION}

This comment has raised the question of whether the corporate defendant's liability for negligence lay in its misfeasance or nonfeasance. No doubt the apparent basis of McKenzie J.'s decision-the corporate defendant's failure to warn the plaintiffs that their goods were uninsured-would point to the latter theory. However, an examination of the nonfeasance theory, and in particular, the source of the corporate defendant's duty of affirmative care, indicates that the defendant's negligence may well have been based on its active misconduct. What were the sources of the corporate defendant's duty of affirmative care? Two possibilities were canvassed. First, it was suggested that the corporate defendant's duty to inform the plaintiffs of their lack of insurance arose from the relationship of bailment. This possibility was rejected on the basis that the duty of affirmative care generated by such a relationship is limited to care that must be exercised in respect to the bailed chattel itself. Secondly, it was suggested that the special and unique relationship of the parties imposed upon the corporate defendant a duty to take affirmative action. However, it was concluded that the ordinary commercial relationship of the parties, even as modified by their friendship, could not in itself justify the imposition of such a duty of care. The 'special relation' basis for the corporate defendant's duty of affirmative care can only be justified on the basis of the theory that the relationship was further modified and defined by representations made to the plaintiffs by the corporate defendant's agent. These representations also provide a basis for the misfeasance theory of the case. Under this theory the source of the corporate defendant's negligence was the misleading impression created by its agent's misrepresentations. In other words, the corporate defendant's negligence was not based on its failure to take affirmative steps to protect the plaintiffs' interests but rather on the active misconduct of its agent who "lulled" the plaintiffs, to their financial detriment, into a false sense of security.

Whether one accepts the nonfeasance or misfeasance theory of the case, the essence of the plaintiffs' claim was their reasonable belief that the corporate defendant would provide for their insurance needs. It has

95. See, for example, Linden's, Canadian Negligence Law 338 (1972).

96. Supra, n. 92 
been suggested in this comment, that in this writer's view, though the plaintiffs' belief was honestly held there was no reasonable basis for such a belief. The importance of the case, however, does not lie in its final result. The importance of the case lies in the theoretical underpinning of the plaintiffs' claim. Unfortunately, this was not fully explored by McKenzie J. in his reasons for judgment. 